\title{
Antioxidant activity of cod (Gadus morhua) protein hydrolysates: Fractionation and characterisation of peptide fractions
}

Farvin Habebullah, Sabeena; Andersen, Lisa Lystbæk; Otte, Jeanette; Nielsen, Henrik Hauch; Jessen, Flemming; Jacobsen, Charlotte

Published in:

Food Chemistry

Link to article, DOI:

10.1016/j.foodchem.2016.02.145

Publication date:

2016

Document Version

Peer reviewed version

Link back to DTU Orbit

Citation (APA):

Farvin Habebullah, S., Andersen, L. L., Otte, J., Nielsen, H. H., Jessen, F., \& Jacobsen, C. (2016). Antioxidant activity of cod (Gadus morhua) protein hydrolysates: Fractionation and characterisation of peptide fractions. Food Chemistry, 204, 409-419. https://doi.org/10.1016/j.foodchem.2016.02.145

\section{General rights}

Copyright and moral rights for the publications made accessible in the public portal are retained by the authors and/or other copyright owners and it is a condition of accessing publications that users recognise and abide by the legal requirements associated with these rights.

- Users may download and print one copy of any publication from the public portal for the purpose of private study or research.

- You may not further distribute the material or use it for any profit-making activity or commercial gain

- You may freely distribute the URL identifying the publication in the public portal 
1 Antioxidant activity of Cod (Gadus morhua) protein hydrolysates: Fractionation and

\section{Characterisation of peptide fractions}

\section{K.H. Sabeena Farvin ${ }^{1 *}$, Lisa Lystbæk Andersen ${ }^{1}$, Jeanette Otte ${ }^{2}$, Henrik Hauch} Nielsen $^{1}$, Flemming Jessen ${ }^{1,}$ Charlotte Jacobsen ${ }^{1}$

${ }^{1}$ Division of Seafood Research, National Food Institute (DTU-Food), Technical University of Denmark. B. 221, SøltoftsPlads, DK-2800 Kgs, Lyngby, Denmark.

${ }^{2}$ Department of Food Science, Faculty of Science, University of Copenhagen, Rolighedsvej 30, DK-1958 Frederiksberg C, Denmark

\section{Running Head: Antioxidant activity of cod protein hydrolysates}

*Corresponding author

K.H. Sabeena Farvin ${ }^{1}$

Division for Industrial Food Research, National Food Institute (DTU-Food), Technical University of Denmark, B. 221, SøltoftsPlads, DK-2800 Kgs, Lyngby, Denmark. Tel. + 4545252559 Fax: + 4545884774

Email: safa@food.dtu.dk; sabeenafarvin@gmail.com Present address: Environment and Life Sciences Research Center, Kuwait Institute for Scientific Research, P.O Box 1638 Salmiya, 22017 Kuwait. Tel:+965 24956319. 
28 This study aimed to characterise peptide fractions ( $>5 \mathrm{kDa}, 3-5 \mathrm{kDa}$ and $<3 \mathrm{kDa}$ ) with 29 antioxidative activity obtained from a cod protein hydrolysate. The free amino acids in all 30 fractions were dominated by Ala, Gly, Glu and Ser. The total amino acid composition had high 31 proportions of Lys, Ala and Glu. The 3-5 kDa and $<3 \mathrm{kDa}$ fractions were further fractionated by size exclusion chromatography. All sub-fractions showed high $\mathrm{Fe}^{2+}$ chelating activity. The DPPH radical scavenging activity of the 3-5 $\mathrm{kDa}$ fraction was exerted mainly by one sub-

34 fraction dominated by peptides with masses below 600 Da. The DPPH radical scavenging 35 activity of the $<3 \mathrm{kDa}$ fraction was exerted by sub-fractions with low molecular weight. The 36 highest reducing power was found in a sub-fraction containing peptides rich in Arg, Tyr and 37 Phe. Both free amino acids and low molecular weight peptides thus seemed to contribute to the antioxidative activity of the peptide fractions, and Tyr seemed to play a major role for the 39 antioxidant activity.

41 Key Words: Cod protein hydrolysates, Antioxidant, Peptides, Amino acids, LC-MS /MS characterization 


\section{Introduction}

The substitution of synthetic antioxidants by natural ones is gaining interest due to the consumers' health concerns associated with the use of synthetic food additives. The utilization of peptides or hydrolysates from dietary proteins for food and/or cosmetic applications has been increasing in recent years because of their low cost, safety, and high nutritional or physiological value (Hattori, Yamaji-Tsukamoto, Kumagai, Feng \& Takahashi, 1998). Fish protein hydrolysates, obtained by controlled enzymatic hydrolysis, are reported to be good in terms of nutritional properties as they have a balanced amino acid composition and high digestibility (Kristinsson \& Rasco, 2000). Also, research on fish protein hydrolysates demonstrated that they contain short chain peptides with certain biological properties such as angiotensin converting enzyme (ACE) inhibitory, antioxidative, anticancerous and hypocholesterolemic activities (Wergedahl, Liaset, Gudbrandsen, Lied, Espe, Muna, et al., 2004; Kim and Mendis, 2006; Ryan, Ross, Bolton, Fitzgerald \& Stanton, 2011; Farvin, Andersen, Nielsen, Jacobsen, Jakobsen, Johansson, \& Jessen, 2014).

In our earlier study on cod protein hydrolysates (Farvin et al., 2014), we investigated the antioxidant activity of crude protein hydrolysates and the fractions thereof obtained by ultra filtration (UF) [ $>5 \mathrm{kDa}, 3-5 \mathrm{kDa}$ and $<3 \mathrm{kDa}$ ] both in in vitro assays and in $5 \%$ fish oil-inwater emulsions. When tested in 5\% oil-in-water emulsions, all the fractions, including the crude protein hydrolysate, were able to protect fish oil against iron catalyzed oxidation (Farvin et al., 2014). The emulsions containing peptide fractions at a concentration of $4.5 \mathrm{mg} / \mathrm{mL}$ showed lower peroxide values (PV) than those with $2 \mathrm{mg} / \mathrm{mL}$, except in the emulsion containing the peptide fraction $<3 \mathrm{kDa}$, where the $\mathrm{PV}$ were higher for the higher concentration of peptides than for the lower concentration. In in vitro assays we found that the $<3 \mathrm{kDa}$ fraction had very good radical scavenging activity, $\mathrm{Fe}^{2+}$ chelating activity, and reducing power, while 
the fraction 3-5 $\mathrm{kDa}$ resulted in a higher protection against oxidation in a liposome model system (Farvin et al, 2014). The antioxidant activity of peptides is closely related to their amino acid constituents and their sequences (Chen, Muramoto, Yamaguchi, Fujimoto \& Nokihara, 1998). Therefore, the objectives of the present study were to investigate the amino acid composition of these fractions and to further characterize the peptides in the most active fractions by LC-MS/MS. This was done by further fractionation using size-exclusion chromatography (SEC) followed by comparison of the antioxidant activity of each sub-fraction and relating it to the composition of the fractions. Each SEC sub-fraction was characterised with respect to peptide profiles, and the nature of the antioxidant peptides and/or amino acids conferring the highest antioxidant activity. This should make it possible to produce a hydrolysate fraction highly suitable for application in foods as a natural antioxidant.

\section{Materials and methods}

\subsection{Materials and chemicals}

A commercial Cod protein hydrolysate, MariPep C, made from North Atlantic cod of consumption quality with commercial proteases, was kindly donated by Marinova, Danish Fish Protein, Hoejmark, DK-6940-Denmark. MariPep C was supplied as a spray-dried product with the following composition: Dry matter $97.60 \%$, protein $75.18 \%$, salt $19.92 \%$, and fat $<0.30 \%$. The amino acid standards, taurine, anserine, and carnosine, as well as L- $\alpha$ phosphatidyl choline, 1,1-diphenyl-2-picryl-hydrazyl (DPPH), thiobarbituric acid, ascorbic acid, and ethylene diamine tetra acetic acid (EDTA) were obtained from Sigma-Aldrich (Steinheim, Germany). All other chemicals used were analytical grade reagents obtained from Merck (Darmstadt, Germany). 
91 The sequential fractionation of protein hydrolysates was done according to our earlier study 92 (Farvin et al., 2014) by ultrafiltration with $5 \mathrm{kDa}$ and $3 \mathrm{kDa}$ molecular weight cut off (MWCO) membranes (polyethersulfone membrane, Sartorius Stedim Biotech, Aubagne, France), resulting in three fractions; $>5 \mathrm{kDa}, 3-5 \mathrm{kDa}$ and $<3 \mathrm{kDa}$, which were freeze-dried and kept in air tight containers at $-80^{\circ} \mathrm{C}$ until further use.

\subsection{Analysis of free amino acids, and anserine and carnosine in UF fractions}

Analysis of free amino acids was performed using LC-MS as described by Farvin, Baron, Nielsen, Otte and Jacobsen, (2010) with some modifications. The crude hydrolysate and the three fractions ( $>5 \mathrm{kDa}, 3-5 \mathrm{kDa}$ and $<3 \mathrm{kDa}$ ) were analysed for the content of free amino acids and the dipeptides anserine and carnosine. Between 25 and $135 \mathrm{mg}$ of sample material was dissolved in $1.0 \mathrm{~mL}$ water and the amino acids were derivatized using the EZ: Faast kit from Phenomenex A/S (Allerød, Denmark). Sample volumes of $2 \mu \mathrm{L}$ were injected into the HPLC mounted with the reversed phase column EZ: Faast AAA-MS ( 250 x 3.0 mm; PhenomenexA/S Allerød, Denmark) and eluted at $35{ }^{\circ} \mathrm{C}$ with a flow rate of $0.5 \mathrm{~mL} / \mathrm{min}$. The mobile phase A was water containing $10 \mathrm{mM}$ ammonium formate and mobile phase $\mathrm{B}$ was methanol containing $10 \mathrm{mM}$ ammonium formate. The gradient was obtained by a linear increase from 60 to $83 \% \mathrm{~B}$ in $20 \mathrm{~min}$. Then the column was re-equilibrated to $60 \% \mathrm{~B}$ until the end of the run (26 min). The eluate was transferred to the on-line mass spectrometer (Agilent 1100, Agilent Technology, Waldbronn, Germany) where amino acids were ionised using APCI (Atmospheric pressure chemical ionisation) with a chamber temperature of $450{ }^{\circ} \mathrm{C}$, and mass spectra were obtained by positive ion mode scanning from 100 to $600 \mathrm{~m} / \mathrm{z}$. Amino acids were identified by comparison of masses of the obtained peaks with masses in the standard table from the Faast Kit, except for taurine. Detection of the taurine standard was not possible when using the Faast Kit, but could be detected by direct injection of the standard in the LC-MS. Hence, samples 
115 were analysed for taurine by direct injection. The levels of free amino acids, carnosine and anserine were quantified based on peak areas of known concentrations of the standards.

117 2.4. Amino acid composition of peptides in the crude hydrolysate and UF fractions

118 For determination of total amino acids, $50 \mathrm{mg}$ of the hydrolysate and different fractions were 119 hydrolysed overnight in $2 \mathrm{~mL} 6 \mathrm{M} \mathrm{HCl}$ in sealed ampoules. The samples were appropriately 120 diluted and filtered through a $0.2 \mu \mathrm{m}$ membrane filter before derivatization of amino acids and 121 analysis of amino acid content as described by Farvin et al (2010).

122 2.5. Size exclusion fractionation of the low molecular weight UF fractions

123 The molecular weight distribution of the $3-5 \mathrm{kDa}$ and $<3 \mathrm{kDa}$ fractions was analyzed by 124 applying $200 \mu \mathrm{L}$ of the fractions (at $30 \mathrm{mg} / \mathrm{mL}$ protein) on a Sephadex G-25 Superfine column $125(2.6 \times 64 \mathrm{~cm})$ and eluting with a buffer containing $50 \mathrm{mM}$ Na-phosphate, $50 \mathrm{mM} \mathrm{NaCl}, \mathrm{pH}$ 126 7.2. For large-scale fractionation of these fractions, $5 \mathrm{~mL}$ samples containing $200 \mathrm{mg}$ and 150 127 mg protein, respectively, were applied to the Sephadex G-25 Superfine column. Seven and ten 128 sub-fractions were collected from the 3-5 kDa and $<3 \mathrm{kDa}$ fractions, respectively. Peptide content was measured with the Pierce BCA Protein Assay (Thermo Scientific; Rockford, IL, USA) using BSA as standard. The 3-5 kDa sub-fractions were tested directly for antioxidant

131 activity, whereas the $<3 \mathrm{kDa}$ sub-fractions, which had very low protein concentrations, were 132 freeze-dried and re-dissolved in deionised water to obtain suitable protein concentrations.

134 The antioxidant activity of the sub-fractions was determined by three in vitro assays testing the 135 DPPH radical scavenging activity, reducing power, and $\mathrm{Fe}^{2+}$ chelating activity, as described by 136 Farvin et al., (2014). The sample concentration used for the assay was $0.5 \mathrm{mg} / \mathrm{mL}$. 
LC-MS/MS analyses were performed as described by Otte, Shalaby, Zakora, Pripp, \& El-

139 Shabrawy (2007) using an Agilent 1100 MSD Trap with Chemstation for LC 3D systems Rev.

140 B.01.03 (Agilent Technologies 2001-2005) and Trap Control software version 5.3 (Bruker

141 Daltonics GmbH 1998-2005). $50 \mu \mathrm{L}$ of fractions were injected and eluted in 75 min using a gradient with $100 \% \mathrm{~A}(0.1 \%$ TFA in water) for 5 min followed by a linear increase to $60 \% \mathrm{~B}$ (0.1\% TFA in $90 \%$ acetonitrile) over the next $70 \mathrm{~min}$. Additional analyses of selected samples were performed with gradients of $0-40 \%$ B or 0-25\% B in 75 min. Online MS/MS spectra were recorded using the range 150-2000 m/z and the target mass $1521 \mathrm{~m} / \mathrm{z}$; in some cases another analysis was made with target mass 322 or $622 \mathrm{~m} / \mathrm{z}$. AutoMS(2) spectra were recorded from two precursor ions with the Smart Parameter Setting on.

Average mass spectra from entire chromatograms were made in order to detect dominating masses in interesting samples; these were then searched in the chromatogram in

150 order to find their retention times. Mascot generic files generated from the whole

151 chromatograms (for all AutoMS (n) compounds detected from 0 to $75 \mathrm{~min}$ ) of interesting

152 fractions were used to search Mascot for protein identification. The search was performed with the Swissprot or NCBInr database, no cleave, 1-3 positive charges, ESI-Trap and 1 Da tolerance. These spectra were also subjected to De Novo sequencing using PEAKS Online 2.0. Furthermore, individual MS/MS spectra obtained with the $1521 \mathrm{~m} / \mathrm{z}$ target mass were analysed with BioTools software (Bruker Daltonics Bio Tools 3.0, Copyright ${ }^{\circledR}$ 1999-2004 Bruker

157 Daltonik GmbH). Initially, to find sequences that were suggested to occur in the peptide the RapiDeNovo sequencing feature was used with hydroxyproline as an optional proline modification. Secondly, the Sequence Editor tool was used to match individual MS/MS spectra

160 to theoretical MS/MS spectra of peptides with same masses that occur in known cod protein 161 sequences and collagen sequences from other fish species (since sequences from cod collagens 
162 were not present in UniProtKB). The sequences used were the following: Beta-actin

163 (B3GDZ9), Beta-actin (G2PDJO), Actin (Q91037), Fast skeletal myosin heavy chain

164 (Q8JIV5), Myosin heavy chain fragment (Q98SS9), Myosin heavy chain large fragment

165 (Q8JIV4), Myosin heavy chain (Q98954), Fast skeletal muscle Troponin I (Q8QG69), Fast

166 skeletal muscle Troponin T (Q8JJ07), and Japanese ricefish $\alpha 1$ a type II collagen (D6RUX4),

167 Japanese ricefish $\alpha 3$ type I collagen (A8QX86), Rainbow trout $\alpha 1$ type I collagen (O93485),

168 Rainbow trout $\alpha 2$ type I collagen (O93484), Rainbow trout $\alpha 3$ type I collagen (O93486).

169 Unfortunately, these sequences did not show the position of the hydroxyproline residues, so it

170 was not possible to search for sequences containing hydroxyproline in these proteins.

$171 \quad$ 2.7. Statistical analyses

172 The data obtained for in vitro assays were analysed by one-way analysis of variance (ANOVA).

173 The statistical comparisons among the samples were performed with a Bonferroni multiple

174 comparison test using the statistical package program Graphpad Prism 4 (Graphpad

175 Software Inc.,San Diego, USA). A p-value $<0.05$ was considered as being statistically 176 significant.

\section{Results and discussions}

179 3.1. Characterisation of UF-fractions

180 3.1.1. Free amino acids, anserine and carnosine

181 The levels and composition of free amino acids and naturally occurring dipeptides may give

182 further detailed information regarding the antioxidant activities of protein hydrolysates. The 183 contents of free amino acids in the crude cod hydrolysate and the different UF-fractions are 184 shown in Table 1. In general, the relative content of the different amino acids (expressed as \% 185 of total free amino acids) was similar in all fractions. The predominant amino acids in all 

$15 \%$ and $10-11 \%$ of the total free amino acids content, respectively. This is in line with the findings of Limin, Feng \& Jing, (2006) showing that Glu was one of the most abundant free amino acids in muscle of marine fishes. As expected, the $<3 \mathrm{kDa}$ fraction had the highest total content of free amino acids among the UF-fractions, whereas the $>5 \mathrm{kDa}$ fraction had the lowest content. When comparing the absolute concentrations of amino acid in the different fractions, the $<3 \mathrm{kDa}$ fraction had a higher content of 13 out of the 19 amino acids than the two other fractions. This could be explained by its higher total content of free amino acids. Interestingly, the 3-5 kDa fraction had similar or higher concentrations of Ala, Arg, Ser, and Gly than the $<3 \mathrm{kDa}$ fraction despite its lower total content of free amino acids. The $>5 \mathrm{kDa}$ fraction did not contain a higher concentration of any amino acid than the two other fractions. Neither the dipeptide carnosine ( $\beta$-alanyl-histidine) nor taurine were detected in any of the samples, while anserine ( $\mathrm{N}$-methyl carnosine) was found in all samples. Taurine is present in fish muscle in relatively high concentrations (Shiau, Pong, Chiou, \& Tin, 2001). Therefore, it was somewhat surprising that it was not detected. Perhaps taurine, which can bind to other biomolecules due to its zwitter ionic properties (Wright, Tallan \& Lin, 1986), was bound to larger peptides and was not extracted together with free amino acids. reported to have antioxidant activity in sunflower oil emulsions (Riison, Sims, \& Fioriti, 1980). Proline has been reported to have antioxidative capacity equivalent to that of Butylated hydroxyanisole (BHA) in sardine oil (Revanker, 1974). Good antioxidant activity has also been reported for His and Trp in both linoleic acid and methyl linoleate systems (Marcuse, 1962). His exhibits strong radical-scavenging activity due to the presence of the imidazole ring (Yong 
211 other fractions may thus be due the presence of higher absolute amounts of His, Lys and Met

212 than in the other fractions (Table 1). However, His also has a strong tendency to invert to a pro-

213 oxidative compound at higher concentrations (Marcuse, 1962). Moreover, the antioxidant role

214 of His in different lipid oxidation systems is not consistent. Erickson, Hultin, \& Borhan (1990)

215 found that His stimulated the oxidation of flounder sarcoplasmic reticulum, while Karel et al.

216 (1966) reported that His inhibited lipid oxidation in a freeze-dried model system. The ability

217 of His to accelerate Fe-dependent peroxidation has also been reported (Din, Schaur \&

218 Schauenstein, 1988). This is in agreement with the poor performance of the $<3 \mathrm{kDa}$ fraction

219 compared to the other fractions in 5\% oil in water emulsions when oxidation is induced by iron

220 (Farvin et al., 2014). Park, Nakamura, Sato, \& Matsumura (2012) reported that Arg, Trp, Met,

221 Met + Arg, and Met + Trp have pro-oxidative effects in emulsion systems, while Met + His

222 have antioxidative effects. So the antioxidative or pro-oxidative effect of amino acids is not

223 solely determined by the individual amino acids but also by the combination of these.

224 The dipeptides, anserine and carnosine, play a number of physiological roles such as

225 control of enzyme activities, neurotransmitter function and inhibition of oxidative reactions

226 (Quinn, Boldyrevt \& Formazuyk, 1992). Wu, Shiau, Chen and Chiou (2003) also demonstrated

227 that carnosine and anserine were antioxidants preventing lipid peroxidation in a linoleic acid

228 system and also possessing DPPH radical scavenging activity, reducing power, and ability to

229 chelate copper and iron. Since carnosine was not detected in the present study, anserine, which

230 was detected in all fractions, most likely contributed to the antioxidant activity of all fractions,

231 including the crude protein hydrolysates, in the 5\% oil in water emulsion (Farvin et al., 2014)

\subsubsection{Amino acid composition}

233 The amino acid compositions of the peptides in the different UF-fractions are given in Table

234 2. All the samples had high proportions of Gly, Glu, Lys, and. Ala. This is in line with the 
observations of Jensen, Larsen, Rustard and Eilertsen (2013), who reported that the most abundant amino acid in cod muscle is Glu and that other abundant amino acids include Asp, Ala, Leu and Lys. The crude hydrolysate and the $>5 \mathrm{kDa}$, and 3-5 kDa fractions had higher proportions of Gly, Pro (nonpolar amino acids) and Asp (polar amino acid) than the $<3 \mathrm{kDa}$ fraction. The $<3 \mathrm{kDa}$ fractions in turn had higher proportions of the polar amino acids His, Ala and Met, and the non-polar amino acids Leu and Ile than the other fractions. Some amino acids reported to exert antioxidant effects, such as Lys, and Tyr (Marcuse, 1962), were abundant in all the peptide fractions. Since the levels of His, Ala, Leu, and Lys were higher in $<3 \mathrm{kDa}$ fraction (Table 2), this fraction contained peptides including these amino acids, which probably contributed to its antioxidant activity. The antioxidant activity of peptides not only depends on the amino acid composition but also on the sequence and configuration of the peptides (Chen et al., 1998). Additional compositional and structural information of the peptides in these UFfractions was obtained, after size-exclusion fractionation, from determination of their peptide profiles and amino acid sequences.

\subsection{Characterisation of sub-fractions obtained by size-exclusion chromatography}

In order to find out what causes the unique in vitro antioxidant activities of the $3-5 \mathrm{kDa}$ and $<3$

$\mathrm{kDa}$ fractions, we further fractionated these fractions by size exclusion chromatography and collected 7 sub-fractions (F) from the 3-5 kDa fraction and 10 sub-fractions (F') from the $<3$ kDa fraction, as shown in Fig. 1a and 2a, respectively.

\subsubsection{Antioxidant activity of sub-fractions}

The antioxidant activity of the sub-fractions, i.e. the DPPH radical scavenging capacity, $\mathrm{Fe}^{2+}$ chelating activity and reducing power are shown in Figure 1(b-d) and Figure 2(b-d). The $\mathrm{Fe}^{2+}-$ chelating activity and reducing power were not significantly different $(\mathrm{p}>0.05)$ between the 
sub-fractions obtained from the 3-5 kDa fraction (Fig. 1b, 1c) indicating that peptides of varying sizes have the ability to bind iron. However, the DPPH radical scavenging activity was significantly $(\mathrm{p}<0.05)$ higher for sub-fraction F8 and significantly $(\mathrm{p}<0.05)$ lower for subfraction F2 when compared to the other sub-fractions (Fig. 1d). In the case of the $<3 \mathrm{kDa}$ fraction, more than 95\% chelating activity was observed in all sub-fractions, and there was no significant difference ( $\mathrm{p}>0.05$ ) between sub-fractions (Fig. $2 b)$. The DPPH radical scavenging capacity and the reducing power showed some differences among the sub-fractions (Fig. 2c and 2d) with sub-fractions F6' to F11' showing higher DPPH radical scavenging activity than F2' to F5' (Fig. 2d). Furthermore, sub-fraction F9' showed significantly $(p<0.05)$ higher reducing power than the other sub-fractions (Fig. 2c).

\subsection{2. $L C-M S$ Characterization of sub-fractions}

All gel filtration sub-fractions from the 3-5 kDa fraction contained a multitude of closely eluting peptides (with varying intensity according to the gel filtration profile shown in Fig. 1a), as can be seen from the peptide profiles shown in Fig 1e. The most interesting sub-fraction from the 3-5 kDa fraction was F8, which had a high DPPH radical scavenging activity and the highest reducing power (Fig. 1c and d). We examined in more detail the profile of this subfraction together with the profile of F4 (Fig. 1f), which contained the highest concentration of peptides but had a lower antioxidant activity (Fig 1). The reason for the higher DPPH radical scavenging activity of F8 in comparison to F4 could either be due to its higher content of hydrophilic amino acids and dipeptides (high peak with elution at $~ 2 \mathrm{~min}$ ) or to the presence, among the multitude of peptides with low abundance (eluting between 10 and $70 \mathrm{~min}$ ), of one or more very potent radical scavenging peptides. An initial attempt to identify peptides using Mascot search for all detected AutoMS(n) compounds in both fractions, did not result in any hits from fish or from major proteins expected in the fish samples (actin, myosin, collagen 
troponin etc), so this did not lead to reliable identification of any of the peptides present in F4 and F8. In previous studies, low molecular weight compounds with DPPH radical scavenging activity extracted from meat products, such as free amino acids and dipeptides, were found to elute near the void volume in RP-HPLC (Broncano, Otte, Peron, Parra, \& Timon, 2012). Accordingly, the high peak at around 1.5 min (Fig. 1f) was higher in the profile of F8 (1.65 versus 1.35 AU for F4) and the shape was different, indicating a different composition of hydrophilic compounds in these samples. Comparison of the average mass spectra of material eluting from 1 to 5 min for F4 and F8 (data not shown) showed that some new compounds were present in F8, i.e. masses 175.1, 209.0, 246.0, 260.1, 274.1, 345.3, 361.1, 375.2, and 402.2. These masses might represent di- and oligopeptides and fragments thereof created during ionisation. The mass 175 could stem from free Arg or y1 ions from peptides with Cterminal Arg. Neither masses for anserine nor other free amino acids present in the 3-5 kDa fraction (Table 1) were found in the average mass spectrum of the early eluting compounds in F8. Some di-, tri- and tetra-peptides that could fit with the other masses detected and their MSMS spectra are given in Table 3. Due to the many possibilities these small peptides could not be unambiguously identified. This would demand other methods, e.g. purification of each peptide and subsequent sequencing. The presence of Glu, Gly, Lys, Ala and Arg in the tentatively identified oligo peptides in F8 of the 3-5 kDa fraction (Table 3) is consistent with the amino acid composition of this fraction (Table 2). Of these amino acids, the charged residues Glu, Lys and Arg might confer antioxidant and metal chelating activity to these early eluting oligopeptides (Saiga, Tanabe, \& Nishimura, 2003). Acidic and basic amino acid containing peptides have been reported to possess very good antioxidant activity (Saiga et al., 2003).

Average mass spectra for all compounds eluting after $5 \mathrm{~min}$ in the two gel filtration samples F4 and F8 (data not shown) confirmed the separation according to size obtained by 
gel filtration (Fig. 1a), since F4 contained peptides with higher masses, mainly between 1000 and 1600 Da (not shown), whereas F8 contained mainly peptides with masses below 600 Da, and only a few with masses $>1000 \mathrm{Da}$, all representing singly charged peptides (Table 3). All the major masses observed in both the average mass spectrum and the small distinguishable peaks in F8 (highlighted masses in Table 3) had a 10 times lower abundance in F4. These masses could thus represent peptides with antioxidant activity. Possible sequences of the major peptides in F8 are shown in Table 3. However, for most of the peptides many possible sequences could fit reasonably well to the fragment peaks, so an unequivocal identification was not attained. It was interesting to note, however, that many of the peptides tentatively identified in this sub-fraction contained His $(\mathrm{H})$ and Tyr $(\mathrm{Y})$ which are known to confer antioxidant properties to peptides (Chen et al, 1998). The higher DPPH scavenging activity of F8 fraction might stem from the peptides containing these amino acids in this sub-fraction. The radical scavenging activity of protein hydrolysates from edible meat was attributed to the presence of His, Tyr, and Met (Saiga et al., 2003). Since there were many peptides in each sub-fraction of the 3-5 $\mathrm{kDa}$ fraction, and the peptides could not be identified with certainty, the activity of the sub-fractions could not be related to particular peptides present in the fraction. also contained a multitude of closely eluting peptides with varying intensity as can be seen from their peptide profiles shown in Fig 2e. However, the later fractions (F8'-F11') contained less and more separated peaks. The most interesting SEC sub-fraction from this UF fraction ( $<3 \mathrm{kDa}$ ) was F9' which showed both a high DPPH radical scavenging activity and a high reducing power. This is in contrast to sub-fractions F6' and F8', which showed high radical scavenging activity but low reducing power. Sub-fractions F8' and F9' contained slightly more early eluting compounds ( $2 \mathrm{~min}$ ) than F6', in agreement with their content of lower molecular masses according to elution in gel filtration. The peptide profiles of F8' and F9' were clearly 
different but had some peptides in common (Fig. 2f), which might be the ones contributing to the radical scavenging activity of these fractions. The dominating masses in F9' found both in the average mass spectrum and in chromatographic peaks were 338, 288, 395, 322, 317, 720, 453, 979, 629 and 621 (Table 4). These were all more abundant in F9' than in F8' and were only present with low abundance in F6'. From the peptide profile (Fig. 2f, bottom panel) the peptides with retention times 22, 29-30, 37 and 55 min, with masses 322, 451, 720, 629 and 621, seem to be dominating in F9' and might be among those with the high reducing power in F9'. According to the tentative identifications (Table 4), the peptides with masses 322 and 451 contain Arg and 322 supposedly also Phe, both of which can contribute to their antioxidant activity (Power, Jakeman, \& FitzGerald, 2013). The peptides with masses 720 and 629 most probably contained fragments from collagen rich in Pro, Ala and Gly. This fits with the high concentration of Ala in the $<3 \mathrm{kDa}$ fraction (Table 2). Many collagen and gelatin-derived peptides have been reported to have antioxidant and antihypertensive or ACE inhibitory activity partly due to their unique Gly-Pro-Hyp sequence in their structure (Kim and Mendis, 2006). The high His content of this UF fraction (Table 2) might be present in peptides eluting mainly in other gel filtration sub-fractions or being present as free histidine (Table 1). Because of different enzyme used, difference in species tested and lack of information about cod peptides in the literature, direct comparison of our results on cod peptide constituents to other studies are not feasible. The sequences suggested in Table 3 and 4 do not seem to be identical to antioxidative peptides previously identified in hydrolysed Pollack skin and meat or other

352 fish hydrolysates (Ryan et al., 2011; Gómez-Guillén, Giménez, López-Caballero, \& Montero, 353 2011) and thus represent novel antioxidative peptides from fish sources. 
355 In our previous study (Farvin et al., 2014), the antioxidant activity of the peptides derived from

356 Cod protein hydrolysate was evaluated by several assays evaluating different reaction

357

358

359

360

361

362 mechanisms and in 5\% oil in water emulsion. In these studies, the low molecular weight fraction $<3 \mathrm{kDa}$ was shown to have the highest radical scavenging activity, reducing power and iron chelating activity and the 3-5 kDa fraction showed higher inhibition of TBARS formation in liposome model system and in 5\% oil in water emulsions (Farvin et al., 2014). In the following section, we will try to relate the antioxidant activities of the fractions to their composition.

The antioxidant activity of proteins and peptides has been reported to be related to their amino acid composition, sequence/structure and hydrophobicity (Chen et al., 1998). A number of studies have observed a high correlation between certain amino acid residues and the antioxidant activity of peptides. The importance of these amino acid residues is believed to be related to their unique structural features. Aromatic amino acids such as Tyr, His, Trp and Phe and hydrophobic amino acids including Val, Leu and Ala, as well as Met and Gly, have been reported to be critical for the antioxidant activities of peptides, although some of these amino acids, such as Gly, Met and Trp, have also been reported to show pro-oxidative effects under certain experimental conditions (Chen et al., 1998; Rajapakse, Mendis, Jung, Je, \& Kim, 2005b). Several studies have shown that a high content of hydrophobic amino acids is mainly responsible for the potent radical-scavenging and lipid-peroxidation inhibitory activities of peptide fractions, e.g. from jumbo squid-skin gelatin, hoki-skin gelatin and giant squid muscle (Mendis, Rajapakse, Byun, \& Kim, 2005a; Mendis, Rajapakse, \& Kim, 2005b; Rajapakse, Mendis, Byun \& Kim, 2005a). Hydrophobic residues, such as Val, Leu and Tyr, can enhance the solubility of peptides in a lipid matrix improving the accessibility to hydrophobic radical species or polyunsaturated fatty acids (Qian, Jung, \& Kim, 2008) and potentially increase their concentration at water-lipid interfaces and allow close contact with lipid molecules, thus 

et al., 2005a; Saiga et al., 2003). Most of the peptides identified in the F8 sub-fraction of 3-5 $\mathrm{kDa}$ contained at least one of these amino acid residues (Table 3) which might be the reason for the better performance of the 3-5 kDa fraction in lipid containing system such as liposomes and in 5\% oil in water emulsion (Farvin et al., 2014). Moreover, the F8 sub-fraction contained a number of peptides with His (peaks with retention time 17.5, 23.9, 28.2, 30.9, 36.7, and 37 min). The antioxidative activity of histidine-containing peptides can exceed that of histidine itself, a phenomenon that may partly result from increased hydrophobicity of the peptides, which increases the interaction between the peptides and fatty acids (Saiga et al., 2003). Phenylalanine, which is also an important constituent in the medium and late eluting peptides from the F8 sub-fraction of 3-5 kDa and also in the F9' sub-fraction of $<3 \mathrm{kDa}$ (Table 3 and Table 4), may also increase the hydrophobicity of peptides. A number of antioxidant peptides reported from different fish sources such as grass carp muscle hydrolysate (Ren, Zhao, Shi, Wang, Jiang, Cui, et al., 2008), horse mackerel visceral proteins (Kumar, Nazeer, \& Jaiganesh, 2011), giant squid muscle (Rajapakse et al., 2005a), sauce of fermented blue mussel (Rajapakse et al., 2005b) also contained Phe. It is therefore presumed that the presence of hydrophobic amino acids in these fractions might have contributed to the inhibition of lipid peroxidation by increasing solubility of peptides in lipid, and thereby facilitating better interaction with radical species. Furthermore, Phe might also act as hydrogen donor, and also as a direct radical scavenger (Zhang, Zhang, Wang, Guo, Wang, \& Yao, 2009). The higher radical scavenging and reducing power of the F9' sub-fraction might stem from such peptides (Table 4). reported earlier. Bougatef, Nedjar-Arroume, Manni, Ravallec, Barkia, Guillochon et al., (2010) reported an antioxidant peptide with the sequence Gly-Gly-Glu. In our study also we could find this peptide as such or in part in the F9' sub-fraction of $<3 \mathrm{kDa}$ (peaks with retention time 37.2 
min in Table 4). Je, Park and Kim (2005) have reported an antioxidant peptide with the

406

407

408

409

410

411

412

413

414

415

416

417

418

419

420

421

422

423

424

425

426

427

428

429 sequence Leu-Pro-His-Ser-Gly-Tyr. In the present study the F8 sub-fraction of 3-5 kDa contains part of this sequence -Leu-Pro-His and -Pro-His (peaks with retention times 23.9 and 37 min). Hernandez-Ledesma, Miralles, Amigo, Ramos, and Recio, (2005) identified eight antioxidant peptides from fermented milk, and seven of the eight peptides identified contained at least one proline residue, and six of them had more than two residues of proline. Similarly, hydrolysates of jumbo flying squid skin gelatin had a scavenging effect on radicals, probably because of the presence of Pro residues in the peptide sequence ( $\mathrm{Lin}$ and $\mathrm{Li}, 2006$ ). Accordingly, a number of the peptides mentioned in Table 3 and Table 4 contained Pro residues and thus may potentiate their antioxidant activity.

The position of amino acids in the $\mathrm{N}$ and $\mathrm{C}$ terminus of the peptide is reported to be important predictors of the antioxidant activity (Chen et al., 1998). The hydrophobic properties of the N-terminal amino acids are important and will increase the antioxidant activity of the peptides. It has been reported that many antioxidant peptides contain the hydrophobic amino acid residues $\mathrm{Val}$ or Leu at the N-terminus of the peptides and Pro, His or Tyr in the sequence (Chen et al., 1998; Uchida \& Kawakishi, 1992). This is consistent with some of the peptides present in the sub fraction F8 from the 3-5 kDa fractions containing Val at the N-terminal and Pro in their sequence (peak with retention time 17.5 Table 3). In addition, some peptides have histidine at the N-terminal (peaks with retention time 28.2, 30.2, 30.9, and 51.9 min in Table 3, and $16.4 \mathrm{~min}$ in Table 4), at which position it has been reported to be effective in metal ion chelation (Chen et al., 1998).

The electronic charge properties (i.e. net charge, molecular polarity) of the C-terminal amino acid are also an important predictor of antioxidant activity (Power et al., 2013). His and Pro have been described as the most important residues in the lipoprotein peroxidationinhibitory activity of peptides isolated from soybean $\beta$-conglycinin hydrolysates (Chen et al., 
1998). Chen et al. (1996) designed 28 synthetic peptides following the structure of an antioxidative peptide (Leu-Leu-Pro-His-His) from digestion of soybean protein and compared their antioxidative activities against peroxidation of linoleic acid. It was revealed that the antioxidant activity of a peptide was more dependent on His residue at the C-terminus in the Leu-Leu- Pro-His-His domain, and that the activity was decreased by removing a His residue from the C-terminus. Similarly, in the present study also some of the peptides present in subfraction F8 from the 3-5 kDa fraction contains di-, tri- and tetra-peptides with C-terminal His residues with Leu or Pro in their sequence (Peak with retention time of 23.9). The higher protection of 3-5 kDa against oxidation in liposomes and in 5\% oil in water emulsion might be due to the presence of these kinds of peptides. Saito, Jin, Ogawa, Muramoto, Hatakeyama,

440 Yasuhara, et al., (2003) also concluded that amino acid sequence influenced the antioxidant activity, and showed that tripeptides containing Trp or Tyr at the C-terminus had strong radical scavenging ability. The LC-MS/MS charcterisation of sub-fractions from $<3 \mathrm{kDa}$ revealed that the sub-fraction F9' contained tripeptides with Tyr (peaks with retention times 15.1 and 16.4 min) and Trp (peak with retention time 37.2) at the C-terminus. Similarly, the sub fraction F8 of 3-5 kDa also contained a tripeptide with Tyr at the C-terminal (peak with retention time 28.4 min). The higher radical scavenging activity of $<3 \mathrm{kDa}$ and 3-5 $\mathrm{kDa}$ fraction might stem from these Tyr and Trp containing tripeptides in these fractions. The antioxidative activities of Trp and Tyr may be explained by the special capability of phenolic and indolic groups to serve as hydrogen donors. The phenoxyl and indoyl radicals are much more stable and have longer lifetimes than simple peroxy radicals, so any reverse reaction or the propagation of the radicalmediated peroxidizing chain reaction are inhibited (Saito et al., 2003). Similarly, the radical scavenging activity was related to the presence of specific amino acid residues such as Met, Tyr, Arg and Pro in the peptides (Power et al., 2013). A number of peptide sequence identified 
in F9' sub-fraction of $<3 \mathrm{kDa}$ contained one or more these amino acid residues (Table 3) which may the reason for the higher radical scavenging activity of these fractions.

456

\section{Conclusion}

458 Overall, our findings suggest that the presence of both antioxidant peptides and free amino acids in the cod protein hydrolysates significantly contribute to the high oxidative stability of 5\% fish oil in water emulsions containing such hydrolysates (Farvin et al. 2014). Free amino acids with antioxidative properties (e.g. Lys, Met and His) were present in all fractions, and the total content of free amino acids were higher in the $<3 \mathrm{kDa}$ fraction compared to other fractions. In addition, a large number of peptides were identified in the low molecular weight UF fractions (3-5 kDa and $<3 \mathrm{kDa}$ ), among them some containing Lys, Arg and His. Further sub-fractionation according to size showed that the high DPPH radical scavenging activity and reducing power in the 3-5 $\mathrm{kDa}$ and $<3 \mathrm{kDa}$ fractions may stem mainly from low molecular weight peptides with a high abundance of Glu, Gly, Lys, Ala, Arg, His, Tyr, Pro and Phe. All sub-fractions showed very good iron chelating activity. These results point to the applicability of these naturally occurring antioxidant peptides as an ingredient in other food products in order to increase their oxidative stability. However, further studies are needed to evaluate their antioxidant activity in more complex food systems were the oxidation is induced by more than one mechanism.

473

\section{Acknowledgments}

475 The authors are thankful to the Danish Research Council for Technology and Production (grant 274-08-0365) and The Danish Council for Strategic Research (grant 09-063104) for financing the project. The help provided by technicians Inge Holmberg for the HPLC analysis and Kirsten 
478 Sjøstrøm for LC-MS analysis, as well as Rene Thrane for freeze drying is greatly 479 acknowledged.

480

\section{REFERENCES}

482

483

484

485

486

487

488

489

490

491

492

493

494

495

496

497

498

499

500

501

502

503

Bougatef, A., Nedjar-Arroume, N., Manni, L ., Ravallec, R., Barkia, A., Guillochon, D. \& Nasri, M. (2010). Purification and identification of novel antioxidant peptides from enzymatic hydrolysates of sardinelle (Sardinella aurita) by-products proteins. Food Chemistry, 118 , 559-565.

Broncano, J.M., Otte, J., Peron, M.J., Parra, V. \& Timon, M.L. (2012). Isolation and identification of low molecular weight bioactive compounds from fermented "Chorizo" sausages. Meat Science, 90, 494-501.

Chen, H.-M., Muramoto, K., Yamauchi, F. \& Nokihara, K. (1996). Antioxidant activity of designed peptides based on the antioxidative peptide isolated from digests of a soybean peptide. Journal of Agricultural and Food Chemistry, 44, 2619-2623.

Chen, H. M., Muramoto, K., Yamaguchi, F., Fujimoto, K., \& Nokihara, K. (1998). Antioxidative properties of histidine-containing peptides designed from peptide fragments found in the digests of a soybean protein. Journal of Agricultural and Food Chemistry, 46, 49-53.

Din, M. S., Schaur R. J., \& Schauenstein, E. (1988). Uptake of ferrous iron histidinate, a promoter of lipid peroxidation, by Ehrlich ascites tumor cells. Biochimicaet Biophysics Acta, 962, 37-41.

Erickson, M. C., Hultin, H., \& Borhan, M. (1990). Effect of cytosol on lipid peroxidation in flounder sarcoplasmic reticulum. Journal of Food Biochemistry, 14, 407-419.

Farvin, K. H. S., Baron, C. P., Nielsen, N. S., Otte, J.,\& Jacobsen, C. (2010). Antioxidant activity of yoghurt peptides: Part 2 - Characterization of peptide fractions. Food Chemistry. 123, 1090-1097. 
504

505

506

507

508

509

510

511

512

513

514

515

516

517

518

519

520

521

522

523

524

525

526

527

528

529

530

Farvin, K.H.S., Andersen, L.L., Nielsen, H.H., Jacobsen, C., Jakobsen, G., Johansson, I., \& Jessen. F. (2014) Antioxidant activity of Cod (Gadusmorhua) protein hydrolysates: in vitro assays and evaluation in 5\% fish oil- in-water emulsion. Food Chemistry 149, 326-334.

Gómez-Guillén, M.C., Giménez, B., López-Caballero, M.E., \& Montero, M.P. (2011). Functional and bioactive properties of collagen and gelatin from alternative sources: A review. Food Hydrocolloids, 25, 1813-1827.

Hattori, M., Yamaji-Tsukamoto, K., Kumagai, H., Feng, Y., \& Takahashi, K. (1998), Antioxidative activity of soluble elastin peptides. Journal of Agricultural and Food Chemistry, 46, 2167-2170.

Hernandez-Ledesma, B., Miralles, B., Amigo, L., Ramos, M., \& Recio, I. (2005). Identification of antioxidant and ACE-inhibitory peptides in fermented milk. Journal of the Science of Food and Agriculture, 85, 1041-1048.

Je, J-Y ., Park, P-J., \& Kim, S-K. (2005). Antioxidant activity of a peptide isolated from Alaska pollack (Theragra chalcogramma) frame protein hydrolysate. Food Research International, 38, 45-50.

Jensen, I., Larsen, R., Rustad, T., \& Eilertsen, K-E. (2013). Nutritional content and bioactive properties of wild and farmed cod (Gadus morhua L.) subjected to food preparation. Journal of Food Composition and Analysis, 31, 212-216.

Karel, M., Tannenbaum, S. R., Wallace, D. H., \& Maloney, H. (1966). Antioxidation of methyl linoleate in freeze-dried model systems. III. Effects of added amino acids. Journal of Food Science, 31, 892-896.

Kim, S. E., \& Mendis, E. (2006). Bioactive compounds from marine processing by-products a review. Food Research International, 39, 383-393.

Kristinsson, H. G., \& Rasco, B. A. (2000). Fish protein hydrolysates: production, biochemical, and functional properties. Critical Reviews in Food Science and Nutrition, 40, 43-81. 
531

532

533

534

535

536

537

538

539

540

541

542

543

544

545

546

547

548

549

550

551

552

553

554

555

556

557

558

559

Kumar, N. S. S., Nazeer, R. A., \& Jaiganesh, R. (2011). Purification and biochemical characterization of antioxidant peptide from horse mackerel (Magalaspis cordyla) viscera protein. Peptides, 32, 1496-1501.

Lin, L., \& Li, B. (2006). Radical scavenging properties of protein hydrolysates from Jumbo flying squid (Dosidicus eschrichitii Steenstrup) skin gelatin. Journal of the Science of Food and Agriculture, 86, 2290-2295.

Limin, L . , Feng, X., \& Jing, H. (2006). Amino acids composition difference and nutritive evaluation of the muscle of five species of marine fish, Pseudosciaena crocea (large yellow croaker), Lateolabrax japonicus (common sea perch), Pagrosontusm ajor (red seabream),S eriola dumenTl( Dumeril's amberjack) and Hapalogenysn itens (black grunt) from Xiamen Bay of China. Aquaculture Nutrition, 12,53-59.

Marcuse, R. (1960). Antioxidative effect of amino acids. Nature, 186, 886-887.

Marcuse, R. (1962). The effect of some amino acids on the oxidation of linolenic acid and its methyl ester. Journal of the American Oil Chemists' Society, 39, 97-103.

Mendis, E., Rajapakse, N., \& Kim, S. K. (2005b). Antioxidant properties of a radical scavenging peptide purified from enzymatically prepared fish skin gelatin hydrolysate. Journal of Agricultural and Food Chemistry, 53, 581-587.

Mendis, E., Rajapakse, N., Byun, H. G., \& Kim, S. K. (2005a). Investigation of jumbo squid (Dosidicus gigas) skin gelatin peptides for their in vitro antioxidant effects. Life Sciences, 77, 2166-2178.

Otte, J., Shalaby, S. M., Zakora, M., Pripp, A. H., \& El-Shabrawy, S. A. (2007). Angiotensinconverting enzyme inhibitory activity of milk protein hydrolysates: Effect of substrate, enzyme, and time of hydrolysis. International Dairy Journal, 17, 488-503.

Park, E.Y., Nakamura, Y., Sato, K., \& Matsumura, Y. (2012). Effects of amino acids and peptide on lipid oxidation in emulsion systems. Journal of the American Oil Chemists' Society, 89, 477-484. 
560

561

562

563

564

565

566

567

568

569

570

571

572

573

574

575

576

577

578

579

580

581

582

583

584

585

586

Power, O., Jakeman, P., \& FitzGerald, R. J. (2013) Antioxidative peptides: enzymatic production, in vitro and in vivo antioxidant activity and potential applications of milkderived antioxidative peptides. Amino Acids, 44, 797-820.

Qian, Z-J., Jung, W-K., \& Kim, S-K. (2008) Free radical scavenging activity of a novel antioxidative peptide purified from hydrolysate of bullfrog skin, Rana catesbeiana Shaw. Bioresource Technology, 99, 1690-1698.

Quinn, P J., Boldyrevt, A. A., \& Formazuyk, V. E. (1992). Carnosine: its properties, functions and potential therapeutic applications. Molecular Aspects of Medicine, 13, 379-444.

Rajapakse, N., Mendis, E., Byun, H-G., \& Kim, S-K. (2005a) Purification and in vitro antioxidative effects of giant squid muscle peptides on free radical-mediated oxidative systems.Journal of Nutritional Biochemistry, 16, 562-569.

Rajapakse, N., Mendis, E., Jung, W-K., Je, J-Y., \& Kim, S-K. (2005b). Purification of a radical scavenging peptide from fermented mussel sauce and its antioxidant properties. Food Research International, 38, 175-182.

Ren, J., Zhao, M., Shi, J., Wang, J., Jiang, Y., Cui, C., Kakuda, Y., \& Xue, S. J. (2008). Purification and identification of antioxidant peptides from grass carp muscle hydrolysates by consecutive chromatography and electro spray ionization-mass spectrometry. Food Chemistry, 108, 727-736.

Revankar, G. D. (1974). Proline as an antioxidant in fish oil. Journal of Food Science and Technology, 11, 10-11.

Riison, T., Sims, R. J. \& Fioriti, J. A. (1980). Effect of amino acids on autoxidation of sunflower oil in emulsions. Journal of the American Oil Chemists’ Society, 57, 354359.

Ryan, J. T., Ross, R.P., Bolton, D., Fitzgerald, G.F. \& Stanton, C. (2011). Bioactive peptides from muscle sources. Meat and fish. Nutrients, 3, 765-791. 
Saiga, A.,Tanabe, S., \& Nishimura, T. (2003) Antioxidant Activity of Peptides Obtained from Porcine Myofibrillar Proteins by Protease Treatment. Journal of Agriculture and Food Chemistry, 51, 3661-3667.

Saito, K., Jin, D-H., Ogawa, T., Muramoto, K., Hatakeyama, E., Yasuhara, T., \& Nokihara, K. (2003). Antioxidative Properties of Tripeptide Libraries Prepared by the Combinatorial Chemistry. Journal of Agricultural and Food Chemistry, 51, 3668-3674.

Shiau, C-Y., Pong, Y-J., Chiou, T-K., \& Tin Y-Y., (2001). Effect of starvation on free histidine and amino acids in white muscle of milkfish Chanos chanos. Comparative Biochemistry and Physiology Part B, 128, 501-506.

Uchida, K., \& Kawakishi, S. (1992). Sequence-dependent reactivity of histidine containing peptides with copper (II)/ascorbate. Journal of Food Biochemistry, 40, 13-16.

Wergedahl, H., Liaset, B., Gudbrandsen, O. A., Lied, E., Espe, M., Muna, Z, Mørk, S., \& Berge R. K. (2004). Fish protein hydrolysate reduces plasma total cholesterol, increases the proportion of HDL cholesterol, and lowers acyl-CoA: cholesterol acyltransferase activity in liver of Zucker rats. The Journal of Nutrition, 134, 1320-7.

Wright, C. E., Tallan, H. H., \& Lin, Y. Y. (1986). Taurine: Biological update. Annual Review of Biochemistry, 55, 427-453.

Wu, H., Shiau, C., Chen, H., \& Chiou, T. (2003). Antioxidant activities of carnosine, anserine, some free amino acids and their combination. Journal of Food and Drug Analysis, 11, 148-153.

Yong, S. H., \& Karel, M. (1978). Reaction of histidine with methyl linoleate: Characterization of the histidine degradation product. Journal of American Oil Chemists Society, 55, 352-356.

Zhang, J., Zhang, H., Wang, L., Guo, X., Wang, X., \& Yao, H. (2009). Antioxidant active of the rice endosperm protein hydrolysate: Identification of the active peptide. European Food Research and Technology, 229, 709-719. 
617

618

619

Table 1. Free Amino acid content in $\mathrm{mg} / \mathrm{100g}$ ( $\%$ of total free amino acids) of the crude cod hydrolysate and the UF-fractions there from.

\begin{tabular}{|c|c|c|c|c|}
\hline \multirow[t]{2}{*}{ Amino Acid } & \multicolumn{4}{|c|}{ Fractions } \\
\hline & Crude & $>5 \mathrm{kDa}$ & 3-5 kDa & $<3 \mathrm{kDa}$ \\
\hline Lys & $168.6(7.3)$ & $72.2(8.0)$ & $122.8(8.1)$ & $135.5(8.7)$ \\
\hline Ala & 384.3 (16.6) & $157.3(17.4)$ & 268.9(17.7) & $246.1(15.8)$ \\
\hline Arg & $116.6(5.0)$ & $48.9(5.4)$ & $81.1(5.3)$ & $74.3(4.8)$ \\
\hline Cys & $5.5(0.2)$ & $5.0(0.6)$ & $8.0(0.5)$ & $12.5(0.8)$ \\
\hline Leu & $130.1(5.6)$ & $51.4(5.7)$ & $81.0(5.3)$ & $91.1(5.8)$ \\
\hline Met & $52.6(2.3)$ & $18.3(2.0)$ & $31.9(2.1)$ & $42.1(2.7)$ \\
\hline Phe & $52.2(2.3)$ & $23.9(2.6)$ & $34.4(2.3)$ & $42.5(2.7)$ \\
\hline Pro & 82.9 (3.9) & $31.6(3.5)$ & $56.0(3.7)$ & $63.5(4.1)$ \\
\hline Thr & $93.0(4.0)$ & 31.8 (3.5) & $63.0(4.2)$ & $58.6(3.8)$ \\
\hline Tyr & $60.6(2.6)$ & $23.9(2.6)$ & $34.2(2.3)$ & $49.4(3.2)$ \\
\hline Asp & $80.2(3.5)$ & $23.4(2.6)$ & $38.0(2.5)$ & $44.4(2.8)$ \\
\hline Ser & 248.9(10.7) & $100.8(11.1)$ & $178.2(11.7)$ & $150.6(9.7)$ \\
\hline Glu & $342.3(14.8)$ & $113.1(12.5)$ & 177.5 (11.7) & $192.6(12.4)$ \\
\hline Нур & $17.1(0.7)$ & $6.0(0.7)$ & $11.3(0.7)$ & $8.8(0.6)$ \\
\hline Val & 53.7 (2.3) & $20.2(2.2)$ & $31.4(2.1)$ & $38.6(2.5)$ \\
\hline His & $21.3(0.9)$ & $9.1(1.0)$ & $15.0(1.0)$ & $21.8(1.4)$ \\
\hline Trp & $8.0(0.3)$ & $4.8(0.5)$ & $5.9(0.4)$ & $6.7(0.4)$ \\
\hline Ile & $27.7(1.2)$ & $11.1(1.2)$ & $18.6(1.2)$ & $22.1(1.4)$ \\
\hline Gly & $370.2(16.0)$ & 151.0 (16.7) & 259.6(17.1) & 256.2 (16.5) \\
\hline Taurine & - & - & - & - \\
\hline Total & $2315.7(100.0)$ & $904.2(100.0)$ & $1516.9(100.0)$ & $1557.4(100.0)$ \\
\hline Carnosine $^{1}$ & - & - & - & - \\
\hline Anserine $^{2}$ & 49.4 & 20.7 & 31.5 & 31.6 \\
\hline
\end{tabular}

$620{ }^{1} \beta$-alanyl histidine

$621 \quad{ }^{2} \beta$-alanyl-N-methylhistidine

622 
623 Table 2.Amino acid composition (expressed as \% of total amino acids) of peptides in the crude

624 cod hydrolysateand different UF-fractions from this.

625 Total amino acids includes free amino acids.

\begin{tabular}{|c|c|c|c|c|}
\hline \multirow[b]{2}{*}{ Amino Acid } & \multicolumn{4}{|c|}{ Fractions } \\
\hline & Crude & $>5 \mathrm{kDa}$ & 3-5 kDa & $<3 \mathbf{k D a}$ \\
\hline Lys & 8.4 & 8.5 & 8.7 & 8.8 \\
\hline Ala & 7.7 & 7.8 & 8.2 & 9.2 \\
\hline Arg & 4.9 & 6.9 & 6.8 & 4.7 \\
\hline Cys & 0.3 & 0.2 & 0.2 & 0.1 \\
\hline Leu & 6.9. & 5.8 & 6.0 & 8.1 \\
\hline Met & 1.8 & 1.1 & 2.5 & 3.5 \\
\hline Phe & 3.5 & 2.7 & 2.6 & 3.3 \\
\hline Pro & 6.6 & 7.9 & 6.26 & 3.7 \\
\hline Thr & 2.2 & 2.1 & 2.2 & 2.0 \\
\hline Tyr & 3.2 & 2.2 & 2.5 & 2.7 \\
\hline Asp & 6.3 & 7.5 & 7.9 & 3.8 \\
\hline Ser & 2.7 & 2.5 & 2.6 & 2.4 \\
\hline Glu & 14.5 & 15.1 & 16.9 & 11.3 \\
\hline Нyp & 1.1 & 1.8 & 1.1 & 0.4 \\
\hline Val & 4.4 & 4.1 & 4.4 & 4.8 \\
\hline His & 5.1 & 3.2 & 3.5 & 15.2 \\
\hline Trp & - & - & - & - \\
\hline Ile & 6.9 & 5.8 & 6.0 & 8.1 \\
\hline Gly & 13.4 & 14.7 & 11.8 & 8.0 \\
\hline Total & 100 & 100 & 100 & 100 \\
\hline
\end{tabular}

626 
Table 3. Major masses found in the sub fraction F8 from the 3-5 kDa UF-sample (Figure 1a)

628 and tentative peptide assignment. Masses that were dominating in both the average mass

629 spectrum and in the highest peaks in the peptide profile (Figure 1f) are highlighted. The major

630 fragment resulting from MS (2) fragmentation of each peptide is underlined.

\begin{tabular}{|c|c|c|c|c|}
\hline $\begin{array}{l}\text { Mass } \\
\text { obs. } \\
{[\mathbf{M}+\mathbf{H}]^{+}}\end{array}$ & $\begin{array}{l}\mathbf{R t}^{1}(\mathbf{m} \\
\text { in) }\end{array}$ & MS(2) fragments ${ }^{2}$ & $\begin{array}{l}\text { Sequence present } \\
\text { peptide with score }^{4} \text { and source }\end{array}$ & $\begin{array}{l}\text { Mass } \\
\text { theor. } \\
{[\mathrm{M}+\mathrm{H}]^{+}}\end{array}$ \\
\hline 274.1 & 3.3 & 257.1, 175.0 а.o. & $\begin{array}{l}\text { VGV (15) or } \\
\text { VR (5) collagen, myosin, troponin }\end{array}$ & $\begin{array}{l}274.2 \\
274.2\end{array}$ \\
\hline 260.1 & $\begin{array}{l}3.4- \\
3.9\end{array}$ & $\begin{array}{l}\text { 242.1, 147.0, 129.1, } 84.2 \\
\text { a.o. }\end{array}$ & $\begin{array}{l}\text { LGA (13) or } \mathbf{P G A}{ }^{6}(13) \text { collagen } \\
\text { or } \mathbf{P K} / \mathrm{Q}^{7} \text { (5) collagen, myosin, actin }\end{array}$ & $\begin{array}{l}260.2,26 \\
0.1 \\
260.2\end{array}$ \\
\hline 402.2 & 3.9 & 385.2, 256.1, 211.1 a.o. & $\begin{array}{l}\text {-VAG; KVVG (25)or } \\
\text { AGVVG (23) collagen } \\
\text { or KVR (19) }\end{array}$ & $\begin{array}{l}402.3 \\
402.2 \\
402.3\end{array}$ \\
\hline 345.3 & $\begin{array}{l}4.1- \\
4.7\end{array}$ & $\begin{array}{l}\text { 328.2,310.2, 175.0, 158.1, } \\
\text { a.o. }\end{array}$ & $\begin{array}{l}\text { PGGV (24), I/LGGV }{ }^{8}(24) \\
\text { orIGR (16) }\end{array}$ & $\begin{array}{l}\text { all } \\
345.2\end{array}$ \\
\hline 361.1 & 4.7 & 4.0: 344.1, 326.2, 175.0 & EGR (22) $\square_{2}$-collagen & 361.2 \\
\hline 375.2 & 4.7 & $\begin{array}{l}\text { 4.7: 358.3, 331.2, } 296.1 \\
\text { 256.1,175.1 }\end{array}$ & -AGV; EAGV (41) or EAR (30) & $\begin{array}{l}\text { both } \\
375.2\end{array}$ \\
\hline 524.3 & 17.5 & Many,e.g. $507.3 \underline{175.0}$ & $\begin{array}{l}\text {-DGV;YADGV (54) } \\
\text { or VGPPGP (45)collagen }\end{array}$ & $\begin{array}{l}524.2 \\
523.3 \\
\end{array}$ \\
\hline 371.2 & 17.5 & $353.2,197.0, \underline{147.0,130.0}$ & -TGPP (10) collagen or HSK/Q (9) & 371.2 \\
\hline 478.1 & 21.1 & $460.1,276.1,203.0$ & -GPS;FKPS or KFPS (11) & 478.2 \\
\hline $\begin{array}{l}437.1 \\
253.1 \\
\end{array}$ & 23.9 & $\begin{array}{l}420.3,253.1,235.0,156.0 \\
\text { (from 437)235, } 156\end{array}$ & $\begin{array}{l}\text {-APH; ALPH actin (33) } \\
\text { PH or HP }\end{array}$ & $\begin{array}{l}437.2 \\
253.1 \\
\end{array}$ \\
\hline 538.3 & $\begin{array}{l}28.2 \\
29.0\end{array}$ & 520.2, 401.3 a.m.o. & -ATL/I, or -CCN; HPATL/I (36) & 538.3 \\
\hline 703.3 & 28.4 & 685.3, 522.2, 504.1 a.o. & -DEY; GGYDEY (58) collagen & 703.3 \\
\hline 566.4 & 30.2 & 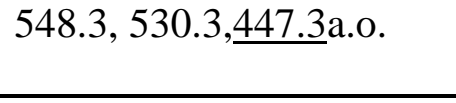 & $\begin{array}{l}\text {-YG or -TTT; YGGGNV (93) } \\
\text { or YNGNV (51) }\end{array}$ & $\begin{array}{l}566.3 \\
566.3 \\
\end{array}$ \\
\hline 554.3 & 30.9 & $\begin{array}{lll}536.5, & 435.3, & 322.1, \\
304.2, & 209.1\end{array}$ & -AI/LT, -APT; HAI/LI/LT (43) & 554.3 \\
\hline 668.3 & 36.7 & 651.2, 537.3, 520.3,a.o. & $\begin{array}{l}\text {-HSHG; HSVRGP (103) or } \\
\text { PMGPPGL (56) collagen }\end{array}$ & $\begin{array}{l}668.3 \\
668.3 \\
\end{array}$ \\
\hline 458.3 & 36.9 & 441.2,345.3, 197.0 a.o. & $\begin{array}{l}\text {-GGVN, -TI/LI/L; PTLL actin, or } \\
\text { I/LTI/LI/L (all 18) }\end{array}$ & 459.3 \\
\hline 657.3 & 37.0 & 639.2,253.0, 235.1 а.0. & $\begin{array}{l}\text {-I/LSF andGYA-;GYALPH(66) } \square- \\
\text { actin }\end{array}$ & 657.3 \\
\hline 593.3 & 37.8 & 576.2, 391.2,244.1a.o. & -SDK or SDQ; MGGSNK (43) n.i. ${ }^{9}$ & 593.3 \\
\hline $\begin{array}{l}419.2 \\
263.1\end{array}$ & 38.0 & $\begin{array}{l}\text { 320.1,263.1,a.o. } \\
\text { (from 419) 215.2, 104.0, } \\
87.1\end{array}$ & VGDE(19) actin & 419.2 \\
\hline
\end{tabular}




\begin{tabular}{|c|c|c|c|c|}
\hline 596.3 & 40.0 & 578.3, 449.2, 336.1 a.o. & $\begin{array}{l}\text {-GEM or -GME;FMGNAG (82) or } \\
\text { MFGPE (66)or YDGPE (62) } \\
\text { or FIGME(58)actin, n.a. }{ }^{10}\end{array}$ & $\begin{array}{l}596.3 \\
596.2 \\
596.3\end{array}$ \\
\hline 565.3 & 40.1 & 547.2,400.2, 382.1,a.o. & $\begin{array}{l}\text {-GVF; WGGVF(90), } \\
\text { or GLGGNF(37)collagen }\end{array}$ & $\begin{array}{l}565.3 \\
564.3\end{array}$ \\
\hline 577.3 & 40.7 & $559.3, \underline{449.2}, 318.2$ & $\begin{array}{l}\text {-GFP -GEM -GFI/L; MGEGAL/I(40) } \\
\text { or OPGFI(19) } \\
\text { or EDKAD (20) troponin I n.a. }\end{array}$ & $\begin{array}{l}577.3 \\
577.3 \\
577.2 \\
\end{array}$ \\
\hline 786.1 & 46.1 & 769.3, 655.3 a.m.o. & TFYNEL (87) actin & 786.4 \\
\hline 1053.6 & 47.0 & $\begin{array}{lll}\begin{array}{l}\text { 1035.6, } \\
\text { a.m.o }\end{array} & 922.4, & 760.4 \\
\end{array}$ & MYPGIADRM (160) actin & 1053.5 \\
\hline 1160.5 & 51.9 & 1143.6, 900.9,6․ㄹ..m.o & MTKHDGMVAGN & 1160.6 \\
\hline 564.3 & 52.7 & No fragments & & \\
\hline 1031.5 & 54.2 & $\begin{array}{l}\text { 903.4,845.4,826.7, 698.1, } \\
\text { 680.0a.o. }\end{array}$ & $\begin{array}{l}\text {-VEDA; GAGVQ/KEGVEDA (307) } \\
\text { or similar }\end{array}$ & 1031.5 \\
\hline 502.8 & 60.6 & 474.3,389.1a.o. & $\begin{array}{l}\text {-AK/QN; PGAK/QN (11) } \\
\text { or PGAAGD (13) }\end{array}$ & $\begin{array}{l}502.3 \\
503.2\end{array}$ \\
\hline 1522.8 & 61.3 & $\begin{array}{l}\text { 1503.9, } \\
\text { 921.5,a.m.o. }\end{array}$ & $\begin{array}{l}\text {-NKE; MEPDMGVEPDNKE (1585) } \\
\text { a.o., n.a. }\end{array}$ & 1522.6 \\
\hline
\end{tabular}

632

633

634

635

636

637

638

639

640

641

642

643

644

645

646

647

${ }^{1}$ Retention time

${ }^{2}$ Fragments obtained by collision induced dissociation, the major one is highlighted

${ }^{3}$ Amino acid sequence suggested to be present in the peptide according to De Novo Analysis using BioTools software

${ }^{4}$ Score is given in () and is the value given by BioTools software for the match of fragments to this sequence.

${ }^{5}$ The protein in which the sequence occurs is given if a reasonable match is found

${ }^{6}$ Modified residues are highlighted $(\mathbf{P}=$ hydroxylated Pro, $\mathbf{M}=$ oxidised Met)

${ }^{7}$ The mass for residues Lys and Glu are both 128 and cannot be distinguished

${ }^{8}$ The mass for residues Ile and Leu are both 113 and cannot be distinguished

${ }^{9}$ n.i. = not identified

${ }^{10}$ n.a. $=$ not all high mass peaks are assigned

a.o $=$ and others

a.m.o=and many others 

and tentative peptide assignment. Masses that were dominating in both the average mass spectrum and in the highest of the peaks in the peptide profile (Figure 2f) are highlighted. The major fragment resulting from MS(2) fragmentation of each peptide is underlined.

\begin{tabular}{|c|c|c|c|c|}
\hline $\begin{array}{l}\text { Mass } \\
\text { obs. } \\
{[\mathbf{M}+\mathbf{H}]}\end{array}$ & $\begin{array}{l}\mathbf{R t}^{\mathbf{1}} \\
(\mathrm{min})\end{array}$ & MS(2) fragments ${ }^{2}$ & $\begin{array}{l}\text { Sequence }^{3} \text { and possible peptide with } \\
\text { score }^{4} \text { and origin }\end{array}$ & $\begin{array}{l}\text { Mass } \\
\text { theor. } \\
{[\mathrm{M}+\mathrm{H}]^{+}}\end{array}$ \\
\hline 338.3 & 8.1 & $\begin{array}{l}\text { 321.1, } 278.1, \quad 175.1 \\
\text { a.o. }\end{array}$ & RY(14) n.a. ${ }^{5}$ & 338.2 \\
\hline 288.1 & 13.7 & $271.1,229.0,180.0$ & no match,n.i. ${ }^{6}$ & \\
\hline 395.2 & 15.1 & 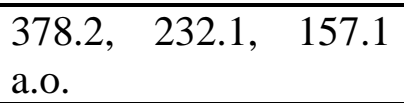 & $\begin{array}{l}\text { MTGS (38)collagen n.a. } \\
\text { orRGY (35)actin n.a., }\end{array}$ & $\begin{array}{l}\text { both } \\
395.2\end{array}$ \\
\hline 390.2 & 16.4 & $372.2,209.0$ a.o. & HAY (23) & 390.2 \\
\hline 409.3 & 16.4 & $\begin{array}{l}\begin{array}{l}\text { 392.2, } \\
\text { a.o. }\end{array} \\
\end{array}$ & RAY(25) & 409.2 \\
\hline 322.2 & 19.2 & 305.1,263.1,175.0 a.o. & RF (17) collagen, or FR(14) & 322.2 \\
\hline 270.3 & 20.0 & 253.1, 211.1 a.o. & n.i. & \\
\hline 451.3 & 21.2 & $\begin{array}{ll}\begin{array}{l}\text { 416.3, } \\
\text { a.o. }\end{array} & 249.1, \quad 175.1 \\
\end{array}$ & $\mathrm{YPR}^{7}(23), \mathrm{YI} / \mathrm{LR}^{8}(23)$ or $\mathrm{EMR}^{7}(23)$ & All451.2 \\
\hline 317.4 & 25.2 & 204.0 a.o. smallpeaks & n.i. & \\
\hline 687.3 & 27.0 & 669.4, 559.3 а.о. & 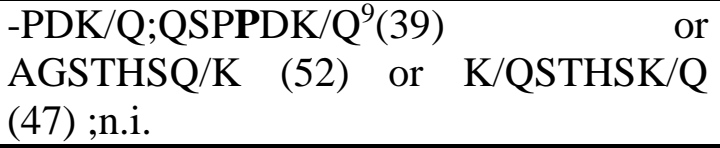 & $\begin{array}{l}687.3 \\
687.4\end{array}$ \\
\hline 720.5 & 28.7 & 702.4, 565.4 a.m.o. & PGPAGPAGP (186)collagen & 720.4 \\
\hline 453.2 & 34.0 & $\begin{array}{l}436.2, \quad 288.2, \quad 243.0, \\
157.0 \text { a.o. }\end{array}$ & $\begin{array}{l}\text { RMF(35), FMR (21)collagen or MRF (20) } \\
\text { or YVGD(18)actin }\end{array}$ & $\begin{array}{l}\text { all } \\
453.2\end{array}$ \\
\hline 979.5 & 36.5 & $\begin{array}{l}\text { 961.4, 850.4, 669.3, } \\
454.3 \text { a.m.o }\end{array}$ & $\begin{array}{l}\text {-KYE; KWEPKYE (148) n.a. or } \\
\text { EPGAAPGVGPAG(27)collagenn.a.; n.i. }\end{array}$ & $\begin{array}{l}\text { both } \\
979.5\end{array}$ \\
\hline 629.4 & 37.2 & 612.3, 482.3 а.о. & $\begin{array}{l}\text {-YSF or YSM; FTK/QSF( } 61) \\
\text { orEQGPAGA (67) collagen }\end{array}$ & $\begin{array}{l}\text { both } \\
629.3 \\
\end{array}$ \\
\hline 446.3 & 37.2 & $\begin{array}{lll}429.3, & 318.2, & 242.1, \\
129.1 & \end{array}$ & $\begin{array}{l}\text {-GGE, I/LGE or PGE; QLGE(29) } \\
\text { collagen,GAIGE(28) collagen } \\
\text { or QIW(20) actin, all fit well }\end{array}$ & $\begin{array}{l}446.2 \\
446.2 \\
446.3 \\
\end{array}$ \\
\hline 792.4 & 47.3 & $\begin{array}{l}775.9, \quad 757.4, \quad 645.4 \\
627.5,599.5 \text { a.o. }\end{array}$ & $\begin{array}{l}\text { GDI/LF; RANGDI/LF (157) or RGSGRIF } \\
\text { (134) or RGYHI/LF(123) or } \\
\text { VGGSGGVME (110) }\end{array}$ & $\begin{array}{l}\text { all } \\
792.4\end{array}$ \\
\hline 621.4 & 55.0 & $\begin{array}{l}605.4, \quad 508.3,462.2, \\
320.0 \text { a.o. }\end{array}$ & $\begin{array}{l}\text {-AVP or AVL/I; NPYVI/Lor PNYVI/L } \\
\text { (16) or similar }\end{array}$ & 621.3 \\
\hline
\end{tabular}

${ }^{1}$ Retention time $\begin{array}{ll}\text { 605.4, 508.3, 462.2, } & \text { (16) or similar } \\ 320.0 \text { a.o. } & \end{array}$

${ }^{2}$ Fragments obtained by collision induced dissociation, the major one is highlighted

${ }^{3}$ Amino acid sequence suggested to occur in the peptide according to De Novo Analysis using BioTools software

${ }^{4}$ Score is given in () and is the value given by BioTools software for the match of the mass peaks to fragments from this sequence. 
${ }^{5}$ n.a. $=$ not all high mass peaks are assigned

$660 \quad{ }^{6}$ n.i. $=$ not identified

$661{ }^{7}$ Modified residues are highlighted ( $\mathbf{P}=$ hydroxylated Pro, $\mathbf{M}=$ oxidised Met)

$662 \quad{ }^{8}$ The mass for residues Ile and Leu are both 113 and cannot be distinguished

$663 \quad{ }^{9}$ The mass for residues Lys and Glu are both 128 and cannot be distinguished

664 
665 Fig.1. Characteristics of the 3-5kDa sub-fractions obtained from Sephadex G-25 666 chromatography with $50 \mathrm{mM}$ Na-phosphate, $50 \mathrm{mM} \mathrm{NaCl}, \mathrm{pH} 7.2$ as eluent. (a) size667 distribution profile with indication of the seven fractions collected. In vitro antioxidant activity 668 measured as (b) Iron chelating activity (c) DPPH radical scavenging activity (d) Reducing 669 power. Results are the mean values of triplicate determinations on the sample \pm standard 670 deviations. Peptide profiles using reversed-phase HPLC (e), and details of these for most active 671 fractions (f).

672

673 Fig.2. Characteristics of the $<3 \mathrm{kDa}$ sub-fractions obtained from Sephadex G-25 674 chromatography with $50 \mathrm{mM}$ Na-phosphate, $50 \mathrm{mM} \mathrm{NaCl}, \mathrm{pH} 7.2$ as eluent. (a) size675 distribution profile with indication of the ten fractions collected. In vitro antioxidant activity 676 measured as (b) Iron chelating activity (c) DPPH radical scavenging activity (d) Reducing 677 power. Results are the mean values of triplicate determinations on the sample \pm standard 678 deviations. Peptide profiles using reversed-phase HPLC (e), and details of these for most active 679 fractions (f)

680 
Fig 1.

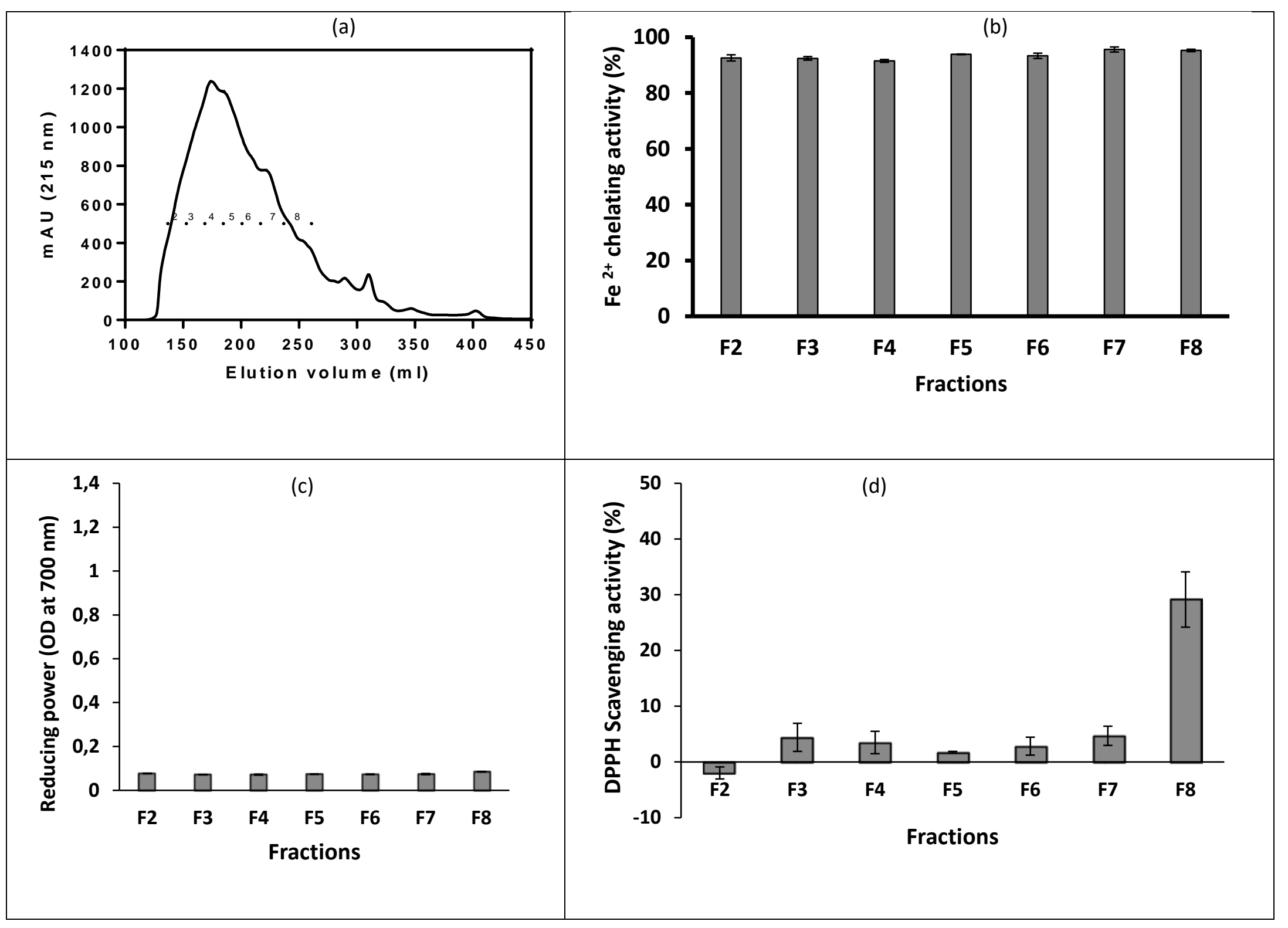




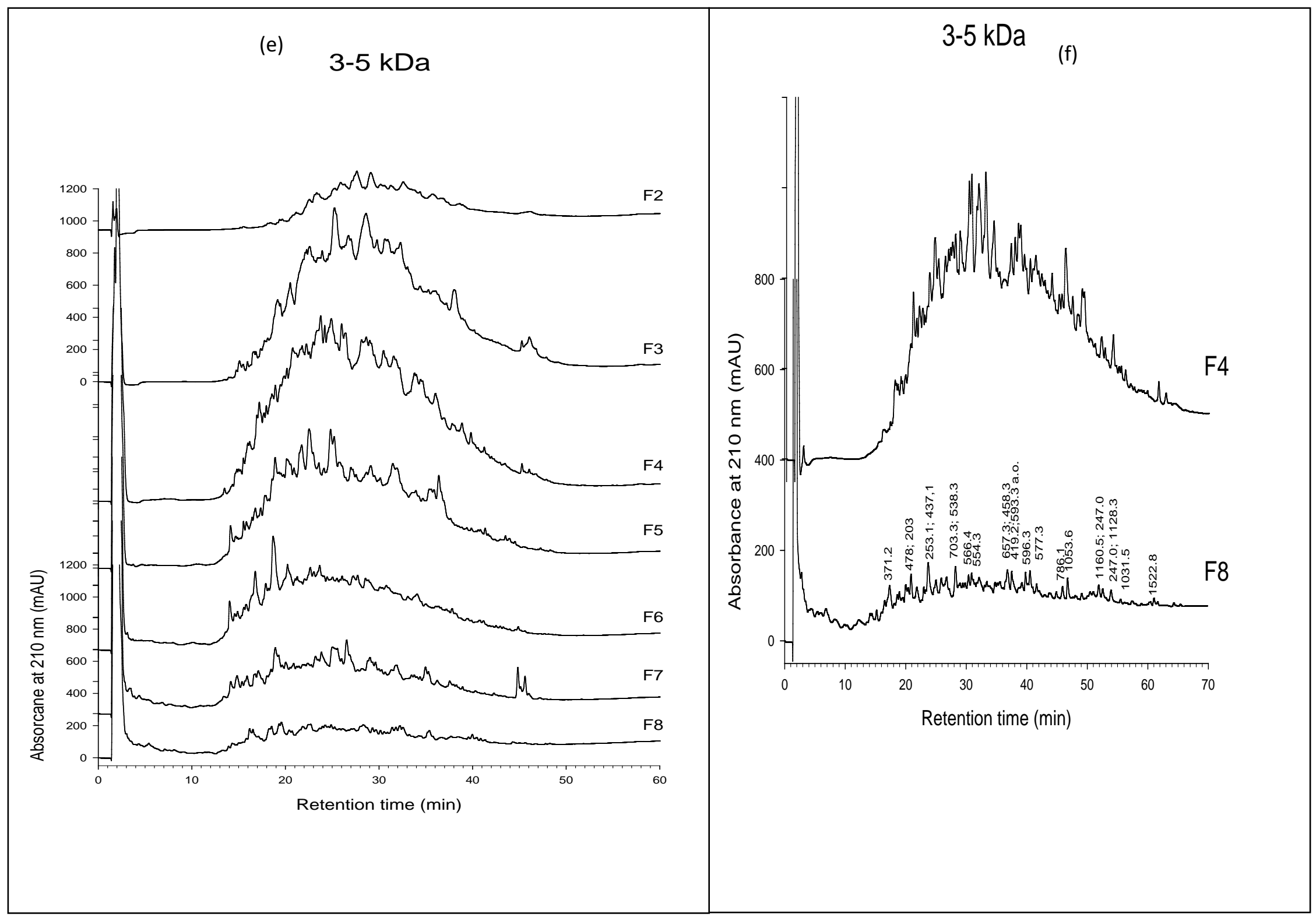




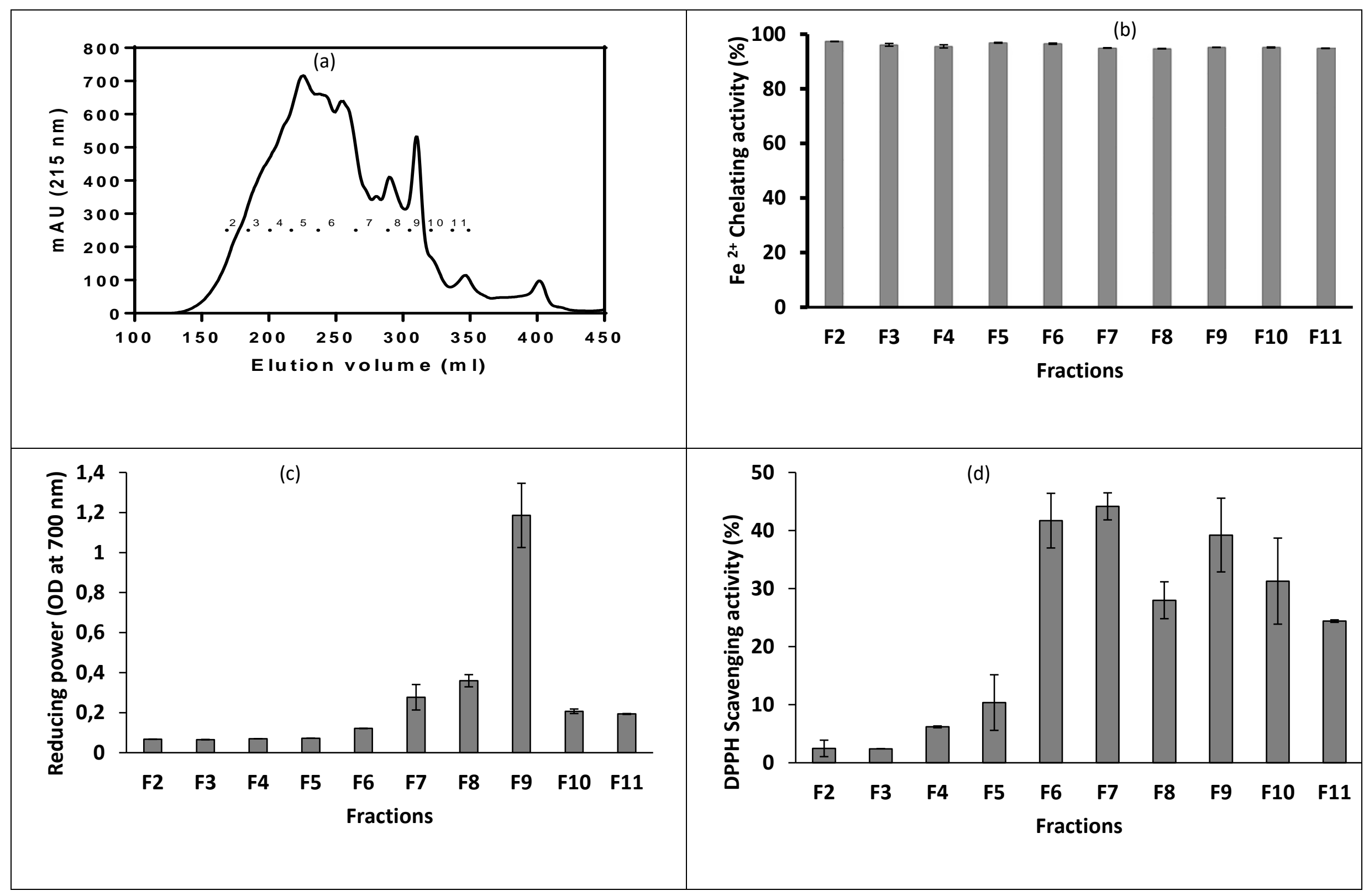




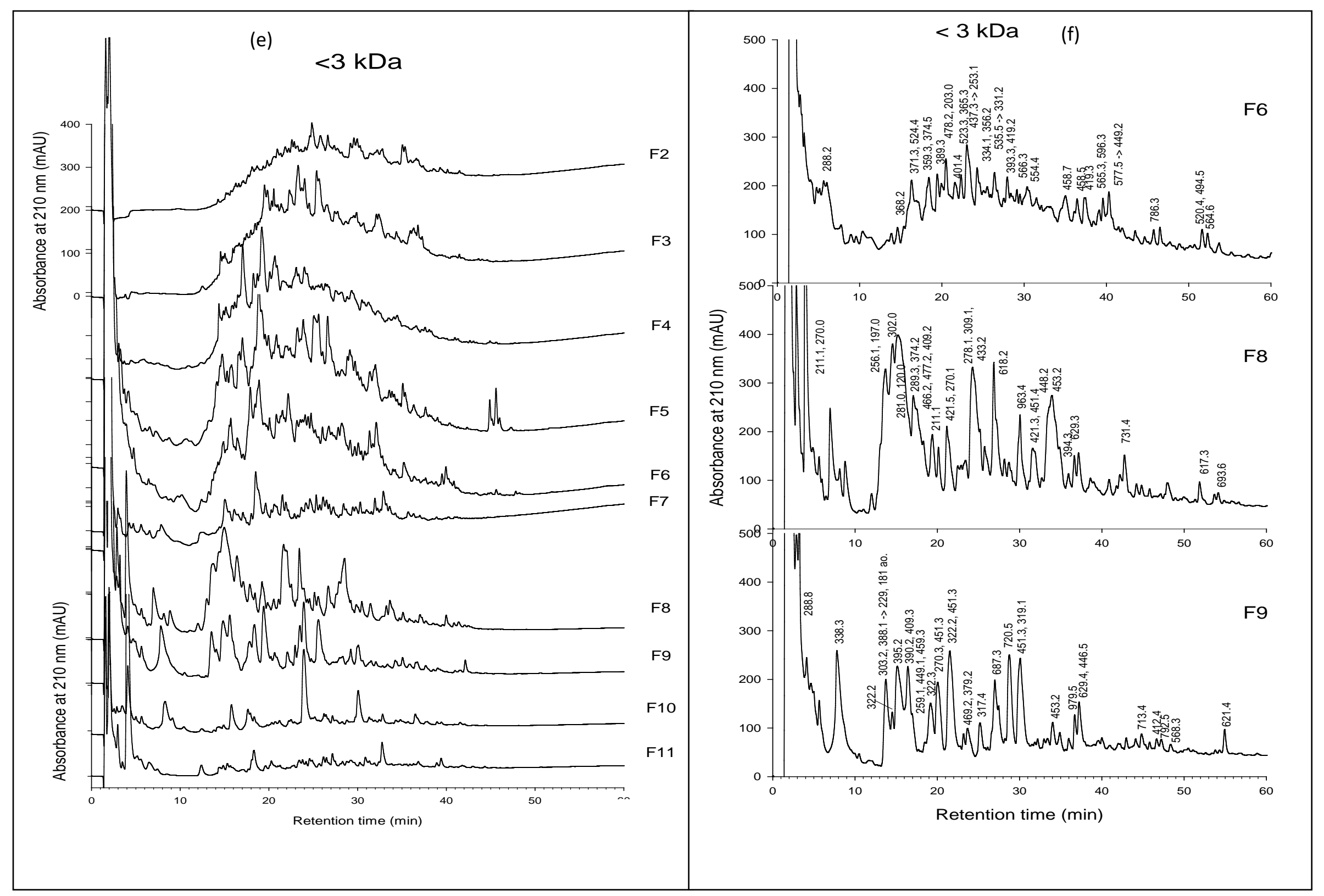

